\title{
Improvement of Cheilitis granulomatosa after Dental Treatment
}

\author{
Ryosuke Sasaki ${ }^{a}$ Kayoko Suzuki ${ }^{b}$ Teppei Hayashic \\ Hiroshi Inasakad Kayoko Matsunaga ${ }^{a}$ \\ ${ }^{a}$ Department of Dermatology, Fujita Health University School of Medicine, \\ Toyoake, ${ }^{b}$ Department of Dermatology, Kariya Toyota General Hospital, Kariya, \\ 'Ai Dental Office, and Inasaka Clinic, Tokai, Japan
}

\section{Key Words}

Cheilitis granulomatosa $\cdot$ Melkersson-Rosenthal syndrome $\cdot$ Dental infection . Dental metals

\begin{abstract}
A 38-year-old male suffered from swelling of the lower lip for 3 months. Neither facial nerve palsy nor fissuring of the tongue was present. Histological examination of a biopsy taken from the lower lip revealed non-caseous epithelioid cell granulomas, suggestive of cheilitis granulomatosa. Patch testing revealed positive reactions to mercury chloride and amalgam. His symptoms markedly improved 3 months after treatment of the apical periodontitis and replacement of dental crowns. As his dental crowns did not contain mercury, we believe that the cheilitis granulomatosa may have been related to the focal dental infection.
\end{abstract}

\section{Introduction}

Cheilitis granulomatosa manifests as edematous swelling of the lips and is considered an incomplete expression of Melkersson-Rosenthal syndrome, a triad of recurrent orofacial edema, recurrent facial nerve palsy and fissuring of the tongue. Various treatments for cheilitis granulomatosa have been reported, but there is no defined treatment for cheilitis granulomatosa. Here, we describe a case of cheilitis granulomatosa that improved after treatment of periodontitis. 


\section{Case Presentation}

A 38-year-old male presented with a 3-month history of persistent lower lip swelling (fig. 1). Neither facial nerve palsy nor fissuring of the tongue was present. Previously, he had been treated with antihistamines, 2 weeks minocycline orally, topical corticosteroid and dapsone without success. Laboratory examination revealed no hematologic or biochemical abnormalities. Patch testing showed positive reactions to $0.05 \%$ mercury chloride and amalgam (both ++ at D4 according to the ICDRG recommendations). Histopathological findings of a biopsy from the lower lip revealed epithelioid cell granuloma (fig. 2 , fig. 3). From the clinical features and histological findings, we diagnosed his condition as cheilitis granulomatosa.

The patient underwent dental treatment to replace his dental metals as he had positively reacted to mercury and amalgam; however, we did not find any mercury in the removed metals. His periodontitis was treated at the same time. Three months after dental treatment, his lip swelling markedly improved.

\section{Discussion}

Cheilitis granulomatosa is a rare disease that manifests as a diffuse and painless swelling of the lips. Melkersson-Rosenthal syndrome consists of the triad of recurrent orofacial swelling, relapsing facial paralysis and fissuring of the tongue. Cheilitis granulomatosa is considered an incomplete expression of Melkersson-Rosenthal syndrome $[1,2]$. The etiology of cheilitis granulomatosa is unknown, but some cases have been associated with Crohn's disease and sarcoidosis [1-3].

Various treatments for cheilitis granulomatosa have been reported, including antibiotics [4, 5], tranilast [6], oral and intralesional steroids [7, 8], and surgical resection [9]. Rapid improvement and/or complete resolution after dental treatment have been reported [1, 10-12]. Worsaae et al. [1] reported that elimination of the dental infectious foci resulted in regression or disappearance of swelling in 11 out of 16 patients. In our case, there was significant improvement of the lip swelling after treatment of the apical periodontitis and replacement of dental crowns. As the replaced dental crowns did not contain mercury, we believe that our case was associated with periodontitis.

We suggest that examination and treatment of focal dental infections is necessary in the treatment of cheilitis granulomatosa. Cases that do not improve after elimination of dental focal infection [8] require further follow-up. 


\begin{tabular}{r|l|l|l}
$\begin{array}{c}\text { Case Reports in } \\
\text { Dermatology }\end{array}$ & $\begin{array}{l}\text { Case Rep Dermatol 2011;3:151-154 } \\
\text { DOI: } 10.1159 / 000330731\end{array}$ & $\begin{array}{l}\text { Published online: } \\
\text { August 9, 2011 }\end{array}$ & $\begin{array}{l}\text { I 2011 S. Karger AG, Basel } \\
\text { ISSN 1662-6567 } \\
\text { www.karger.com/cde }\end{array}$ \\
\hline
\end{tabular}

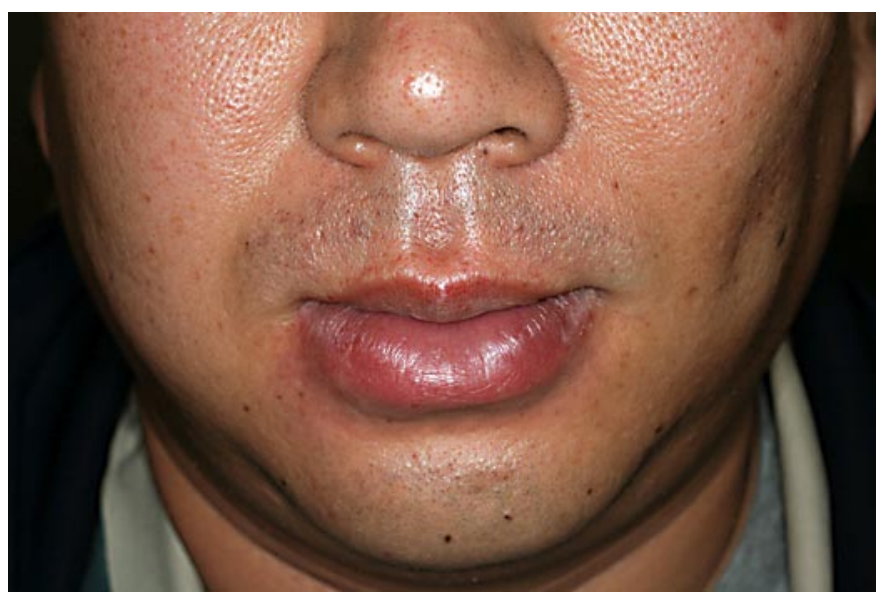

Fig. 1. Clinical appearance at initial presentation showing a marked swelling of the lower lip.

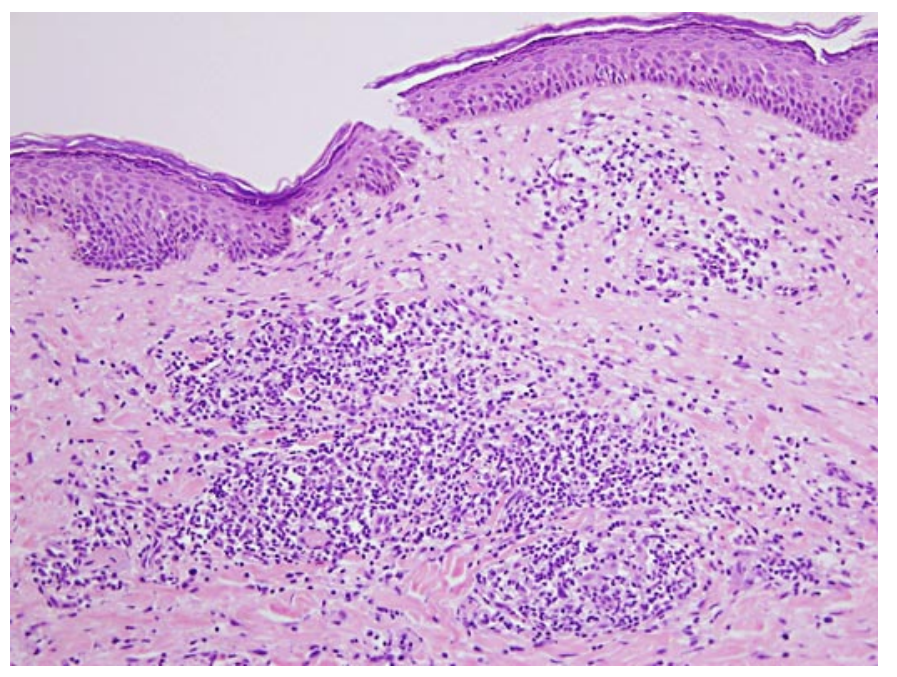

Fig. 2. Histopathology reveals multiple non-caseous epithelioid cell granulomas (HE stain, low magnification). 


\begin{tabular}{c|l|l|l}
$\begin{array}{c}\text { Case Reports in } \\
\text { Dermatology }\end{array}$ & $\begin{array}{l}\text { Case Rep Dermatol 2011;3:151-154 } \\
\text { DOI: 10.1159/000330731 }\end{array}$ & $\begin{array}{l}\text { Published online: } \\
\text { August 9, 2011 }\end{array}$ & $\begin{array}{l}\text { O 2011 S. Karger AG, Basel } \\
\text { ISSN 1662-6567 } \\
\text { www.karger.com/cde }\end{array}$ \\
\hline
\end{tabular}

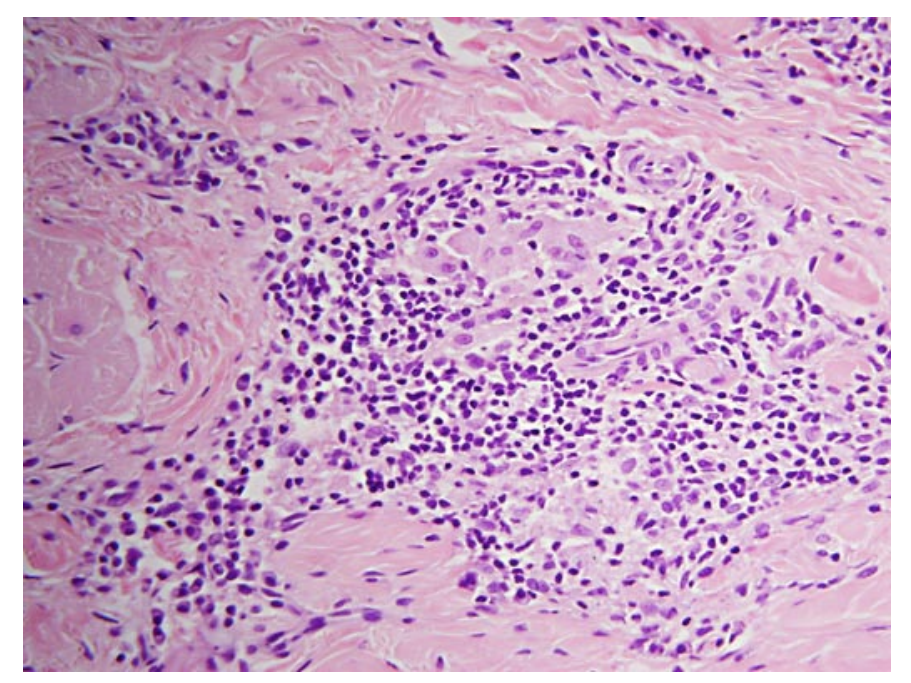

Fig. 3. On higher magnification, non-caseous epithelioid cell granulomas are evident with lymphocytic infiltration (HE stain, high magnification).

\section{References}

1 Worsaae N, Cristensen KC, Schiodt M, Reibel J: Melkersson-Rosenthal syndrome and cheilitis granulomatosa. A clinicopathologic study of thirty-three patients with special reference to their oral lesions. Oral Pathol 1982;54:404-413.

2 van der Waal RI, Schulten EA, van der Scheur MR, Wauters IM, Starink TM, van der Waal I: Cheilitis granulomatosa. J Eur Acad Dermatol Venereol 2001;15:519-523.

-3 Ratzinger G, Sepp N, Vogetseder W, Tilg H: Cheilitis granulomatosa and Melkersson-Rosenthal syndrome: evaluation of gastrointestinal involvement and therapeutic regimens in a series of 14 patients. J Eur Acad Dermatol Venereol 2007;74:1065-1070.

4 Olivier V, Lacour JP, Castanet J, Perrin C, Ortonne JP: Cheilitis granulomatosa in a child. Arch Pediatr 2000;7:274-277.

5 Inui S, Itami S, Katayama I: Granulomatous cheilitis successfully treated with roxithromycin. J Dermatol 2008;35:244-245.

6 Kato T, Yagami H: Successful treatment of granulomatous cheilitis with tranilast. J Dermatol 1986;13:402-403.

7 Bacci C, Valente ML: Successful treatment of cheilitis granulomatous with intralesional injection of triamcinolone. J Eur Acad Dermatol Venereol 2010;24:363-364.

8 Allen CM, Camisa C, Hamzeh S, Stephens L: Cheilitis granulomatosa: report of six cases and review of literature. J Am Acad Dermatol 1990;23:444-450.

-9 Camacho F, García-Bravo B, Carrizosa A: Treatment of Miescher's cheilitis granulomatosa in MelkerssonRosenthal syndrome. J Eur Acad Dermatol Venereol 2001;15:546-549.

10 Takeshita T, Koga T, Yashima Y: Case repot: cheilitis granulomatosa with periodontitis. J Dermatol 1995;22:804-806.

11 Kawakami T, Fukai K, Sowa J, Ishii M, Teramae H, Kanazawa K: Case of cheilitis granulomatosa associated with apical periodontitis. J Dermatol 2008;35:115-119.

-12 Lazarov A, Kidron D, Tulchinsky Z, Minkow B: Contact orofacial granulomatosis caused by delayed hypersensitivity to gold and mercury. J Am Acad Dermatol 2003;49:1117-1120. 